\title{
JOLANTA SAWICKA
}

(Warszawa)

\section{POLITYCZNOŚĆ JAKO OBIETNICA NOWEGO ŚWIATA MYŚL POLITYCZNA HANNAH ARENDT}

Hannah Arendt po wydarzeniach pierwszej połowy XX wieku na nowo chciała odkryć znaczenie polityki i sens tego, co nazywała politycznym doświadczeniem. Najważniejszym przejawem polityczności, pisała, jest działanie, które w jej teorii oznacza śmiałe przedsięwzięcia w mowie i czynie, w towarzystwie równych sobie osób; jest nim także rozpoczynanie, inicjowanie czegoś nowego, czego efektu końcowego nie sposób przewidzieć. Działanie to również składanie obietnic i zdolność przebaczania innym, to ustanawianie dziedziny spraw publicznych. Wszystkiego tego jednostka może doświadczyć jedynie w warunkach wspólnoty, różnorodności i założenia niepowtarzalności ludzi. Działanie i polityczność w ogóle wymagają od jednostek wielu umiejętności, takich jak myślenie, sądzenie, zdolność komunikowania się z innymi i respektowania różnic zachodzących między członkami wspólnot. Powstaje zatem pytanie, czy nie lepiej i łatwiej byłoby, gdyby ludzie pozbyli się polityki i działania politycznego, w zamian decydując się na coś w rodzaju technicznego zarządzania rzeczami i osobami, w celu utrzymania porządku. Z pewnością takie rozwiązanie byłoby łatwiejsze, ale według Arendt, która wyjaśnia sens doświadczeń politycznych (to znaczy odwagi, sławy, godności, równości, wolności), ludzie nie powinni próbować wyzwolić się od polityki, lecz od uprzedzeń i przesądów związanych z polityką. A uwolnienie od utartych opinii, pejoratywnie określających politykę, możliwe jest dzięki ponownemu odkryciu i ocenieniu tego, czym jest działanie i świat ludzi w swej istocie.

W tym miejscu zderzamy się z problem związanym z kryteriami, według których należałoby zredefiniować to, co na ogół rozumiane jest jako możliwości działania. Normy pochodzące czy to z nakazów moralnych, przykazań Bożych, czy też reguł wywiedzionych z niezmiennych praw natury albo związanych z prak- 
tycznymi zasadami postępowania, po Rewolucji Francuskiej, której synonimem dla Arendt jest „zerwanie nici tradycji”, po nazizmie i komunizmie, utraciły jakikolwiek związek z rzeczywistością. Wszelkie dotychczasowe miary stały się bezużyteczne. Ludzie w systemach totalitarnych, donoszący na bliskich i przyjaciół, mordujący się wzajemnie, czynili to nie tylko ze względu na wolę i rozkazy wodza, lecz dopuszczali się tych czynów będąc w zgodzie z ideologicznymi projektami kierującymi społeczeństwami w imię „postępu”, w imię wyższych ideałów, w które uwierzyli. Arendt podkreśla, że czynili to, ponieważ nie dokonali właściwego osądzenia rzeczywistości, to znaczy byli bezmyślni. Dodatkowo stwierdza, że w świetle „praw postępu" zasady pochodzące ze zdrowego rozsądku, rodzinnego oddania, miłości, braterstwa, prawdomówności wydawały się uprzedzeniami, zacofaniem, przesądami i strachem przed tym, co nowe. Stąd przekonanie Arendt, że kryteria tego, co słuszne, a co błędne, dobre albo złe, nie mogą pochodzić z zewnątrz, ponieważ są one apolityczne, a nawet fałszywe. Źródłem wszelkiej miary dotyczącej publicznego świata powinna być ludzka wielość, jako że jest prawem tego świata. Sądy polityczne nie są sprawą związaną z postępem wiedzy, nie usuwają również w całości ryzyka i niepewności, jednak potwierdzają ludzką różnorodność i uwzględniają odmienność zdań, co więcej, ustanawiają rzeczywistość ludzkiej wolności we wspólnocie ${ }^{1}$.

Podstawą filozofii politycznej Arendt jest jej przekonanie, że współczesny kryzys polega na utracie wiary w ludzką racjonalność i siłę umysłu; a co za tym idzie, na przyswojeniu przez człowieka fałszywych wartości, co prawda łatwych (nie wymagających głębszej refleksji), lecz bezwzględnie alienujących jednostkę z relacji ze światem i z innymi ludźmi ${ }^{2}$. Rewolucja Francuska i rewolucja przemysłowa wraz z wyniesieniem pracy, aktywności najbardziej prywatnej spośród innych czynności ludzkich, do dziedziny publicznej, zniszczyły prawdziwy sens polityczności. Przestano dostrzegać i respektować fundamentalne rozróżnienia, ważne dla zachowania harmonii między człowiekiem a światem, odrzucono dystynkcje między innymi takie jak: prywatne - publiczne, ogólne - szczegółowe. W momencie, kiedy sprawy prywatne, czynności ściśle związane z gospodarstwem domowym, rodziną i z koniecznościami życia biologicznego, weszły w obszar publiczny, powstała sfera społeczna uzależniająca człowieka od grupy, wywierająca presje posłuszeństwa i piętnująca wszelkie przejawy odstępstwa od powszechnie przyjętych norm bądź lekceważąco odnosząca się do odmiennych poglądów. W sytuacji, kiedy człowiek postrzegany jest nie jako jednostka, ale jako element ujednoliconej masy, albo też

\footnotetext{
1 Zob. H. Arendt, Polityka jako obietnica, przeł. Wojciech Madej, Mieczysław Godyń, Warszawa 2008, s. 9-10.

2 Zob. R. Skarżyński, Hannah Arendt. Budowanie myśli, „Literatura na świecie”, nr 6 (167), Warszawa 1985.
} 
odwrotnie - jako jednostka wykluczona z przynależności do wspólnoty (na przykład klasowej, lub majątkowej), z przerażającą łatwością pojawia się możliwość podporządkowania pojedynczego człowieka rozkazom, wyższym celom społecznym czy ideologicznym ${ }^{3}$.

Rozróżnienie na sferę publiczną i prywatną jest bardzo ważnym elementem w myśli politycznej Arendt. Funkcjonowanie człowieka w dwóch niezależnych od siebie, ale koegzystujących, obszarach pozwalało na zachowanie proporcji i ładu w świecie wspólnie zamieszkiwanym z innymi. Niemiecka filozofka odwołując się do starożytnej Grecji wskazuje na korzyści, jakie wynikały z pielęgnowania i podtrzymywania granicy między tym, co konieczne, a tym, co ogólnie można określić jako możliwe. Zniszczenie tej dychotomiczności, lecz nie poprzez zniesienie, zupełne wyeliminowanie tego, co zhierarchizowane, konieczne, intymne i biologiczne, a poprzez włączenie wszystkich tych cech do obszaru publicznego, zniekształciło dawny sens tego, co polityczne i negatywnie wpłynęło na człowieka oraz jego dotychczasowe różnorodne sposoby działania i pojawiania się w wspólnym świecie.

W ten sposób wyłoniła się sfera społeczna niebędąca ani prywatną, ani publiczną ${ }^{4}$. Zjawisko to, zdaniem Arendt, zbiegło się z narodzinami epoki nowożytnej. W rozumieniu starożytnych Greków prywatność miała charakter negatywny i deprywacyjny, oznaczała bowiem brak wolności i możliwości dobrowolnego działania. Prywatność głównie określała stan niewolników zmuszonych do ciężkiej i nieustającej pracy. Epoka nowożytna natomiast ze starożytnego pejoratywnego określania prywatności uczyniła pozytywny, odnoszący się do intymności wymiar - nazywając to indywidualizmem, a społeczeństwo jedną wielką rodziną ${ }^{5}$.

3 Szerzej o niszczącej sile tłumów zob. G. Le Bon, Psychologia tłumów, przeł. B. Kaprocki, Kęty 2007.

4 „Społeczeństwem nazywam tę osobliwą, nieco hybrydalną strefę pośrednią, ni to polityczną, ni to prywatną, w której od zarania epoki nowożytnej, większość ludzi spędza przeważającą część swego życia"; H. Arendt, Refleksje na temat Little Rock, w: Odpowiedzialność i wladza sądzenia, przeł. Wojeciech Madej, Mieczysław Godyń, Warszawa 2006, s. 235.

5 Według Georga Simmela epoka Renesansu była tą, która pierwsza ugruntowała pojęcie indywidualności, jako odrębnego stanu wewnętrznego i zewnętrznego od wspólnoty religijno-społecznej, od ogólnie przyjętych form życia ograniczających i homogenizujących grupy. Przy czym renesansowy indywidualizm nazywa Simmel indywidualizmem behawioralnym, charakteryzującym się radykalnością, chęcią ostentacyjnego wyróżnienia się jednostki. Ekstremalność ta, jak pisze Simmel, doprowadziła do takich zjawisk, jak brak panującej mody we Florencji, ponieważ każdy ubierał się według własnego uznania, poza jakimikolwiek normami. Taki stan zindywidualizowania jednak był niewystarczający, a nawet stwarzający utrudnienia, między innymi w postaci nieustannej presji potwierdzania swojej wyjątkowości, swojej inności wobec innych. Pojawiła się zatem nowa forma indywidualizmu, skupiona już nie na różnicy, lecz na wolności. Według Simmela dla wieku XVIII wolność była „uniwersalnym roszczeniem jednostek", a indywidualizm kierowany był głównie chęcią samopotwierdzenia i sprzeciwu wobec społeczeństwa. Simmel wymienia fizjokratów piszących o naturalności wolnej konkurencji, Rousseau jako krytyka społeczeństwa będącego źródłem zła, społeczeństwa ograniczającego i deprawującego jednostkę, rewolucję francuską z terroryzującą wolnością, która w imię swobody zabroniła two- 
Zdaniem Arendt traktowanie dziedziny publicznej na wzór rodziny poprzedzone było upadkiem rodziny jako takiej, w jej „prawidłowym” pierwotnym znaczeniu. Rodzina należała do sfery prywatnej, a wszelka powstająca w niej opinia czy kształtujący się wspólny interes jej członków reprezentowane były wyłącznie przez gospodarza (głowę rodziny). Rozpad rodziny, a następnie wchłonięcie jej przez społeczeństwo, spowodowało, że sposób zorganizowania gospodarstwa domowego przeniesiony został na dziedzinę publiczną. Relacje między członkami nie były wówczas oparte na równości, lecz odpowiadały hierarchicznemu podporządkowaniu jednostce, która uchodziła za silniejszac albo bogatszac pośród innych. Przenosząc swoje konstatacje na czasy współczesne, stwierdza Arendt, że o ile niemożliwe jest już wyznaczenie jednego zwierzchnika w społeczeństwie, to krystalizuje się coś symetrycznego pod postacią jednej wspólnej opinii, jednego wspólnego interesu, czyli - jak mówi filozofka - rządy nikogo, które zamiennie określane są jako biurokracja ${ }^{6}$. Według Arendt jest to najbardziej nieludzka i okrutna forma sprawowania władzy, w której nikt nie ponosi odpowiedzialności ${ }^{7}$.

Hannah Arendt dokonując dokładnej analizy historycznej dotyczącej etapów rozpadu dawnego podziału na prywatne i publiczne piętnuje moment pojawienia się kwestii socjalnych (ekonomicznych) w obszarze publicznym jako główną przyczynę wykluczenia możliwości bezinteresownego działania politycznego. Od tej pory każda jednostka w społeczeństwie domaga się lub oczekuje od innych określonego rodzaju zachowania. A tworzenie nowych reguł, niezliczonych przepisów i norm postępowania służy powszechnej „normalizacji” członków społeczeństwa. Innymi słowy społeczeństwo narzuca zasady i tym samym eliminuje spontaniczność; zabiera przestrzeń, w której możliwe jest wykazywanie się i dokonywanie wybitnych osiągnięć. Od tej pory powszechne normy dyktują, jak powinno się zachowywać, aby nie być odrzuconym, aby nadal uczestniczyć w obrębie porządku ustalonego tak naprawdę przez „nikogo” 8 .

rzenia związków zawodowych robotników. Zob. G. Simmel, Wolność i jednostka, w: Sławomir Magala, Simmel, Warszawa 1980, s. 223-233. Warto zauważyć, że renesansowy indywidualizm ma swoje korzenie w starożytnej filozofii sofistów: Protagors z dewizą „Człowiek jest miarą wszystkich rzeczy" może uchodzić za patrona indywidualizmu najbardziej radykalnego. Za antenatów renesansowych indywidualistów należy także uważać greckich cyników.

6 Zob. H. Arendt, Kondycja ludzka, przeł. Anna Łagodzka, Warszawa 2000, s. 46-47.

7 „W każdym biurokratycznym systemie przerzucanie odpowiedzialności jest na porządku dziennym i jeśli ktoś chce zdefiniować biurokrację w kategoriach nauk politycznych, to znaczy jako pewną formę ustrojową - rządy biur i instytucji w odróżnieniu od rządów ludzi, jednego człowieka, grupy lub masy - to niestety są to rządy nikogo i z tego właśnie powodu jest to chyba najbardziej nieludzka i okrutna forma sprawowania władzy"; H. Arendt, Odpowiedzialność osobista w warunkach dyktatury, w: Odpowiedzialność i wtadza sadzenia, wyd. cyt., s. 64.

8 Zob. H. Arendt, Kondycja ludzka, wyd. cyt., s. 49. 
Działanie, które według Arendt stanowi centrum życia ludzi we wspólnocie, zostało zastąpione zachowaniem ${ }^{9}$. Wspólny interes, jednomyślność opinii oraz liczebność wyznawców tej jednowymiarowości to siła społeczeństwa. I tak jak wcześniej rodzina została była wchłonięta przez ogólnie rozumiane społeczeństwo, tak skutkiem kolejnego kroku „normalizacji” i ujednolicenia było powstanie społeczeństwa masowego. Konsekwencją tego okazała się jednowymiarowość; „wraz z wyłonieniem się społeczeństwa masowego - pisze Arendt - dziedzina tego, co społeczne, po kilku wiekach rozwoju w końcu objęła kontrolą wszystkich członków danej wspólnoty na równi i z jednakową mocą" ${ }^{10}$. Wszelkie odrębności i różnice stały się prywatną sprawą jednostki. Dziedzina publiczna stała się obszarem realizowania doraźnych celów, głównie związanych z wymiarem ekonomicznym.

Arendt, opisujacc w Kondycji ludzkiej proces umasowienia ludzi w przestrzeni publicznej, stale odnosi się do wzoru greckiej polis, w której niemożliwe byłoby takie ujednolicenie. Być dopuszczonym do życia pośród równych sobie bynajmniej nie oznaczało żyć pośród takich samych, jednakowych ludzi ${ }^{11}$. Polis było obszarem, gdzie panowała różnorodność i atmosfera zdrowego agonu - współzawodnictwa. Ujednolicenie było niemożliwe, a wszelkie nawet najmniejsze tego przejawy były eliminowane. Członkowie polis nieustannie chcieli udowadniać sobie i innym, kto jest najlepszy, kto czym się wyróżnia, kto kim naprawdę jest, i czerpali z tego radość. Jasno z tego wynika, że indywidualność jak najbardziej manifestowała się w obszarze publicznym. Co więcej, właśnie dzięki tej sferze indywidualność była pielęgnowana (wszakże nie indywidualność w znaczeniu nowożytnym).

\footnotetext{
9 Należy zaznaczyć, że mimo iż w myśli politycznej Arendt wspólnota jest elementem nieodzownym, to nie stanowi on punktu centralnego, dlatego też nie można zaliczyć autorki do komunitaryzmu. Komunitaryści sądzą, że to wspólnota jest epicentrum refleksji politycznej, a w drugiej kolejności kwestie wolności i równości. U Arendt działanie, wolność i równość stanowią centrum rozważań. Wspólnota jedynie umożliwia realizację działania politycznego. Zob. W. Kymlicka, Wspólczesna filozofia polityczna, przeł. A. Pawelec, Warszawa 2009, s. 259-332; Zob. także A. Swift, Wprowadzenie do filozofii politycznej, przeł. A. Krzynówek, Kraków 2010, s. $135-173$.

10 H. Arendt, Kondycja ludzka, wyd. cyt., s. 47.

11 Równość dla starożytnych Greków oznaczała życie i działanie pośród równych sobie, a więc wolnych od konieczności życiowych. Równość nie była właściwością ludzi, lecz atrybutem polis. Nowożytność natomiast równość połączyła ze sprawiedliwością oraz konformizmem i realizowaniem przyjętego w społeczeństwie zachowania. Konformizm i sztuczna równość natomiast, zdaniem Arendt, zniszczyły polityczność i jej egzystencjalny wymiar. „Izonomia (równouprawnienie - przyp. J.S.) zapewniała istotes (równość), nie dlatego jednak, że wszyscy ludzie rodzili się czy też byli stworzeni jako równi, lecz właśnie dlatego, że z natury (physei) nie byli równi i potrzebowali sztucznie stworzonej instytucji (polis), która mogła uczynić ich równymi na mocy swego prawa (nomos). Równość istniała więc tylko w specyficznym świecie polityki, w którym ludzie spotykali się jako obywatele, nie zaś jako osoby prywatne"; H. Arendt, O rewolucji, przeł. M. Godyń, Warszawa 2003, s. 33.
} 
Od epoki nowożytnej działanie zastąpione zostało zachowaniem, to znaczy, że ludzi nie łączyło już podejmowanie wspólnego przedsięwzięcia, ale normy zachowawcze. Arendt ten konformizm opisuje jako fundament naukowej ekonomii, która powstała wraz z wyłonieniem się społeczeństwa. Głównym narzędziem ekonomii była statystyka, której sens wyznaczany był przez wielkie liczby i długie okresy. Ekonomia i socjologia, według Arendt, redukują człowieka do całości, pozbawiają go spontaniczności w działaniu, gdyż od tego momentu jest on ujmowany matematycznie, tak jak rzeczywistość, w której żyje. Automatyzm i behawioryzm, ujednolicenie i umasowienie to przyczyny uniemożliwienia człowiekowi realizowania politycznej egzystencji; im mniej fluktuacji, odchyleń i odstępstw od normy, tym lepiej, „doskonalej”, ponieważ masa ludzka jest przewidywalna i można nią pokierować w każdym dowolnym kierunku ${ }^{12}$.

Ujednolicenie i niemożliwość sprzeciwienia się wobec powszechnie panujących norm Arendt postrzega jako ogromne zagrożenie dla człowieka, jego zdolności do działania i ogólnie polityki. Społeczeństwo, budowane przez jednostki, które określane są przez statystyczne dane, których zachowanie, wybór, ewentualne działanie, można przewidzieć, wymaga do swego funkcjonowania „komunistycznej wizji”, to znaczy, wspólnego interesu, wspólnej i jednakowej opinii, jak twierdzi niemiecka filozofka ${ }^{13}$.

Społeczeństwo wraz z jego charakterystycznym ujednoliceniem i funkcjonowaniem wedle reguł „komunistycznej fikcji” zastąpiło tradycyjne państwo i rząd administracją, biurokracją, a dziedzinę publiczną - sferą społeczeństwa masowego.

12 W starożytności ekonomia była niewielkim działem etyki i polityki, traktowana jako rodzaj aktywności człowieka. Wraz z powstaniem społeczeństwa i wprowadzeniem wzorów zachowania możliwe było stworzenie koncepcji ekonomii politycznej, co dla starożytnych Greków było wewnętrznie sprzeczne. Ekonomia była częścią sfery prywatnej. Zob. H. Arendt, Kondycja ludzka, wyd. cyt., s. 46-50.

13 „Ujednolicone zachowanie poddające się określeniom statystycznym, a tym samym naukowo poprawnemu przewidywaniu trudno byłoby wyjaśnić hipotezą liberałów mówiącą o naturalnej 'zgodności interesów', która stanowi podwalinę ekonomii 'klasycznej'; to nie Karol Marks, lecz sami liberalni ekonomiści musieli wprowadzić 'komunistyczną fikcję', to znaczy założyć, że istnieje jeden interes społeczeństwa jako całości, który za pomocą 'niewidzialnej ręki' kieruje zachowaniem ludzi i wytwarza harmonię ich sprzecznych interesów". I dalej: "Całkowity triumf społeczeństwa zawsze zrodzi pewnego rodzaju 'komunistyczną fikcję', której szczególnie znamienną cechą jest to, iż naprawdę rządzi nią 'niewidzialna ręka', to znaczy nikt"; H. Arendt, Kondycja ludzka, wyd. cyt., s. 50-51. Warto zaznaczyć, że Arendt krytykując liberalizm i stwierdzając, że posługuje się również komunistyczną fikcją, idzie nieco za daleko. Wspólny interes w komunizmie nie jest tym samym, co w liberalizmie. Komuniści mieli jasno określony cel. Natomiast wspólny interes głoszony przez przedstawicieli liberalizmu to wspólne dobro, ale pod różną postacią się artykułujące: szczęście, realizowanie pasji, praca, pisanie, malowanie - to, co jest tym dobrem, każdy ustala według własnego upodobania. Ważne jest, aby nie szkodzić i nie narzucać innym, swego sposobu uzyskiwania dobra. We wczesnym liberalizmie rynek ustanawia dobro wspólne, ale tylko na poziomie powszechnej wymiany gospodarczej. Warto przy tym pamiętać, że Adam Smith uznał w Teorii uczuć moralnych żal i współczucie za najpierwotniejsze emocje człowieka. Por. A. Smith, Teoria uczuć moralnych, przeł. D. Petsch, Warszawa 1989. 
Zmiana ta sprawiła, że dążenie do doskonałości stało się czymś niepożądanym czy anonimowym. Najważniejszy stał się postęp i ogólna innowacyjność, a nie osiągnięcia poszczególnych ludzi: „Podczas gdy - pisze Arendt - staliśmy się doskonali w pracy wykonywanej publicznie, nasza zdolność działania i mowy w znacznym stopniu utraciła swą dawną jakość od czasu, gdy dziedzina społeczna wygnała ją do sfery intymności i prywatności" 14. Świat, zdaniem Arendt, przestał już być właściwym miejscem dla ludzkiej działalności i doskonałości.

Sfera społeczna to nic innego jak przekształcenie prywatnej troski o własność prywatną w troskę wspólną i publiczną. Społeczeństwo to organizacja posiadaczy własności, którzy zamiast domagać się z racji swego bogactwa dostępu do dziedziny publicznej, żądali jedynie ochrony przed tą dziedziną, w celu dalszego gromadzenia jeszcze większych bogactw ${ }^{15}$. „Społeczeństwo jest formą - pisze Arendt - której fakt wzajemnej zależności w imię potrzeb życia i niczego więcej nabiera znaczenia publicznego, formą, w której zezwala się, by czynności związane ze zwykłym przetrwaniem pojawiły się publicznie" 16 .

Wcześniej bogactwo było czymś, co użytkowano i konsumowano; jeżeli w ciągu życia jednostki niemożliwe było wyczerpanie tych nagromadzonych dóbr, w różnej postaci, to rodzina stawała się właścicielem danej własności. Takie podejście zmieniło się wraz z przekształceniem bogactwa i własności w kapitał, który miał odtąd podlegać procesowi samopomnażania. Wówczas własność prywatna uzyskała trwałość, której przed epoką nowożytną, jak pisze Arendt, nigdy nie miała ${ }^{17}$. Największą jednak szkodą było nie tylko ustanowienie bogactwa i własności jako najważniejszej kondygnacji wspólnego świata, lecz to, że zniesiono tym samym własność prywatną w sensie własnego, namacalnego miejsca w świcie ${ }^{18}$.

Społeczeństwo fikcji, czyli inaczej społeczeństwo masowe, to idealny wzór homogenicznej zbiorowości, w której jednostki zredukowane są do całości, które odgrywają niejako role uwarunkowanych w swych zachowaniach zwierząt, pozbawionych miejsca w świecie i prywatnego domu. Co więcej, specyfiką człowieka ma-

14 H. Arendt, Kondycja ludzka, wyd. cyt., s. 55.

15 W społeczeństwie wspólnota budowana jest na podstawie wspólnego bogactwa, a nie poprzez wspólne działanie. Wcześniej bogactwo czy własność były wynikiem czynności mających miejsce w sferze prywatnej. To, co niegdyś było prywatne, przemijające i kruche, od epoki nowożytnej zaczęło tworzyć świat. Jednak bogactwo, według Arendt, nigdy nie będzie na tyle silne i trwałe, aby tworzyć prawdziwą wspólnotę, bo zawsze będzie czymś prywatnym. Nikt przecież bezinteresownie nie oddaje obcej osobie swojego wynagrodzenia. Bogactwo nie będzie nigdy tym, czym jest wspólny świat. Zob. H. Arendt, Kondycja ludzka, wyd. cyt., s. 75.

16 H. Arendt, Kondycja ludzka, wyd. cyt., s. 53.

17 Tamże, s. 76.

18 Tamże, s. 77. 
sowego jest przede wszystkim odizolowanie i brak normalnych kontaktów międzyludzkich ${ }^{19}$.

Monolityczny charakter społeczeństwa, charakteryzujący się konformizmem, czyli umożliwieniem realizowania tylko jednego interesu i tylko jednej opinii, ma swoja podstawę w jedności gatunku ludzkiego. I z tego powodu, że ta jedność nie jest fantazją ani nawet hipotezą naukową, lecz faktem, że wszyscy należymy do takiego rodzaju, z taką łatwością można kierować zachowaniami ludzi i przewidywać ich potencjalne działanie. Przemoc, terror i propaganda to narzędzia, za pomocą których rządzi się społeczeństwem masowym. Dla Arendt jest to początek totalitaryzmu i koniec człowieczeństwa.

Społeczeństwo masowe to zgodnie myślący tłum ludzi. Kierowanie takim tłumem nie jest specjalnie trudnym zadaniem. Pod matryce jednego interesu bądź jednej opinii można podstawić dowolny interes lub opinię. Wspólnym interesem społeczeństwa masowego może być dążenie do szczęścia, bogactwa, wyeliminowanie wszelkich odmienności klasowych, rasowych etc. Jedna opinia również może odnosić się do różnych zjawisk, a najlepszym odzwierciedleniem jednomyślność jest ideologia ${ }^{20}$.

W rozumieniu Arendt ideologia to system, który wychodząc od jakiegoś pojedynczego twierdzenia, okazuje się wystarczająco silny, by przyciągnąć i przekonać większość ludzi. Okazuje się także dostatecznie pojemny, by móc odpowiedzieć na potrzeby ludzi i prowadzić ich przez różnorodne doświadczenia. Ideologia tym się różni od zwykłych poglądów, że przypisuje sobie posiadanie wszechwiedzy; tworzy wrażenie posiadania klucza do rozumienia dziejów albo patentu na rozwiązywanie wszelkich zagadek świata. Ludzie bezmyślni, to znaczy nie używający swej zdolności sądzenia, bez trudu uwierzą w tę fikcję i będą absolutnie przekonani, że jeden interes i jedna opinia jest uniwersalną prawdą rządzącą przyrodą i człowiekiem ${ }^{21}$. Historia ruchów totalitarnych jest przerażającym potwierdzeniem możliwości stworzenia fikcji, fałszywych wartości i celów, w które $\operatorname{masy}^{22}$ uwierzą.

19 Zob. H. Arendt, Korzenie totalitaryzmu, przeł. D. Grinberg, M. Szawiel, Warszawa 2008, s. 461. Krytyka masowości w wydaniu Arendt zadziwiająco współbrzmi z Buntem mas Ortegi y Gasseta.

20 „Praktycznie nie będzie miało większego znaczenia czy ruchy totalitarne posłużą się wzorcem nazizmu, czy bolszewizmu, czy zorganizują masy w imię rasy, czy w imię klasy, czy będą głosić posłuszeństwo prawom życia i natury, czy prawom dialektyki i ekonomii"; H. Arendt, Korzenie totalitaryzmu, wyd. cyt., s. 456.

21 Zob. tamże, s. 234.

22 Termin „masy” odzwierciedla ogromna ilość ludzi, a także ich bierność. „Potencjalne masy istnieją w każdym kraju, stanowiąc większość pośród rzesz neutralnych, biernych politycznie ludzi (...)"; tamże, s. 453-454. 
Terror, ideologia i bierność ludzi ${ }^{23}$ to całkowite zaprzeczenie polityczności i godności człowieka; te trzy pojęcia to również fundament, na którym opierały się totalitaryzmy. Tyrania, dyktatura, totalitaryzm, wszystkie te formy są zaprzeczeniem pluralizmu politycznego oraz przyczyną zniszczenia wolności. Totalność (ideologii, bierności, strachu) polega na tym, że nie można spojrzeć na nią z zewnątrz i się do tego obiektywnie odnieść. Totalność, o ile bezpośrednio nie wynika z bierności ludzi, z faktu politycznej obojętności czerpie moc, bowiem jej istota polega również na zinternalizowaniu ideologii przez członków ruchu, społeczeństwa, tak bardzo, że staje się nieodłącznym elementem życia, jak gdyby wżerała się w umysły. Komunikacja i relacje między członkami społeczeństwa masowego owładniętego przez totalność są nie tyle niemożliwe, co raczej zbędne. Wielość rozpływa się w „Jednym Człowieku”, a wszelka działalność jest zależna od niepodważalnej, wręcz ,świętej” Woli Dyktatora, wyrażonej wprost lub nie wprost w postaci rozkazów. Widać wyraźnie, że jest to niewątpliwe zniszczenie politycznej sfery działania, wolności, wielości, spontaniczności i tego wszystkiego, co według Arendt stanowiło o politycznej kondycji człowieka. Zredukowanie ludzi do „takożsamości", całkowita unifikacja i masowość to, innymi słowy, apolityczna egzystencja człowieka: „Totalne panowanie - pisze Arendt - nie pozwala na swobodną inicjatywę w jakiejkolwiek dziedzinie życia, na jakąkolwiek aktywność, której nie da się całkowicie przewidzieć. Władza totalitarna nieuchronnie zastępuje wszystkich ludzi wyjątkowo utalentowanych, niezależnie od ich poglądów, takimi szaleńcami i głupcami, w przypadku których brak inteligencji i pomysłowości jest najlepszą gwarancją lojalności" 24.

Totalitaryzm w ramach swego totalnego panowania dokonuje potrójnego morderstwa dokonanego na osobie prawnej, osobie moralnej oraz godności ludzkiej (morderstwa rozumianego również jako zniszczenie indywidualności), aby nieskończoną różnorodność i odmienność istot ludzkich zorganizować tak, aby stały się jednym człowiekiem o niezmiennych powtarzalnych reakcjach, żeby następnie móc każdy zespół zachowań dowolnie wymienić na inny ${ }^{25}$.

Zabicie osoby prawnej to inaczej wyjęcie jednostki spod ochrony prawa, to odebranie obywatelstwa i uczynienie jej bezpaństwowcem, aby prawo nie miało mocy bronienia człowieka, a oskarżenia wszelkiego rodzaju mogły odbywać się bez zbędnych rozpraw i oświadczeń sądowych, na zasadzie arbitralnego aresztowania i ukarania (najczęściej po prostu zabicia albo wywiezienia

23 „Zobojętnienie na własny los, w sensie utraty poczucia własnej ważności i odczuwania własnej zbędności, przerodziło się z objawu indywidualnego idealizmu w zjawisko masowe"; tamże, s. 459 .

24 Tamże, s. 490 .

25 Zob. tamże, s. 615. 
do obozu $)^{26}$. Zabicie osoby moralnej to zniszczenie w człowieku tego, co stanowi o jego człowieczeństwie, o różnicy między jednostką a zwierzęciem. To zafałszowanie miary dobra i zła, podważanie głosu zdrowego rozsądku i sumienia. To stworzenie atmosfery nihilizmu i obojętności; nic nie ma znaczenia: życie, czyny, słowa, śmierć. Uniemożliwienie jednostce dokonania wyboru między dobrem a złem, a jedynie między złem a złem; człowiek ma wybierać, czy zdradzić przyjaciela i tym samym posłać go na śmierć, czy narazić na śmierć swoją rodzinę, jeżeli się nie zdradzi przyjaciela. Totalitarny terror spowodował, że wszelkie decyzje sumienia stały się kwestionowane i niejednoznaczne ${ }^{27}$. Zabicie osoby moralnej to także uczynienie anonimowymi - życia i śmierci: „Obozy koncentracyjne - pisze Arendt - czyniąc samą śmierć anonimową (co uniemożliwiało stwierdzenie, czy więzień żyje, czy nie), pozbawiły ją jej właściwego znaczenia jako końca spełnionego życia. W tym sensie odebrały jednostce jej śmierć, dowodząc, że odtąd nic do niej nie należy, a ona nie należy do nikogo. Jej śmierć pieczętuje tylko fakt, że nigdy nie istniała naprawdę" 28. Zniszczenie godności ludzkiej, indywidualności jednostek, to nic innego, jak swobodne manipulowanie ludźmi, ich losem, ciałem, miejscem przebywania, własnością prywatną, a nawet myśleniem. To innymi słowy zniszczenie tożsamości ludzkiej, spontaniczności, możliwości działania i rozpoczynania czegoś nowego. To wyuczenie człowieka odruchowych reakcji i zachowań. Człowieka można zniszczyć i zamienić na inny egzemplarz; można całkowicie uprzedmiotowić osobę ${ }^{29}$.

W totalitaryzmie wszystko jest możliwe, lecz w zupełnie inny sposób, jak w przypadku działania, które również charakteryzuje się nieprzewidywalnością. Wszystko jest możliwe, bo nie ma żadnych stałych zasad postępowania, nie ma możliwości wybaczania i odpowiedniego ukarania, wyeliminowana jest wszelka właściwie rozumiana odpowiedzialność. Jest za to bezsilność i strach ludzi. Przykładem nieprzewidywalności były obozy koncentracyjne, o założeniu których Arendt pisze tak: „Obozy koncentracyjne oraz obozy zagłady reżymów totalitarnych służą jako laboratoria, w których poddaje się sprawdzeniu podstawowe założenie totalitaryzmu, głoszące, że wszystko jest możliwe. (...) Panowanie totalitarne - stwierdza autorka dalej - usiłuje osiągnąć ten cel stosując zarówno indoktrynację ideową formacji elitarnych, jak i absolutny terror w obozach. Okrucieństwa zaś, do których popełnienia używa się bezlitośnie formacji elitarnych, stają się w rzeczywistości praktycznym zastosowaniem ideologicznej indoktry-

26 Zob. tamże, s. 628-633.

27 Zob. tamże, s. 633-636.

28 Tamże, s. 634.

29 Zob. tamże, s. 611, 615-616, 637-644. 
nacji - polem doświadczalnym, na którym ideologia musi się sprawdzić - natomiast odrażające widowisko samych obozów ma być »teoretycznym《 uzasadnieniem ideologii" 30 .

Dlaczego tak wielu ludzi uwierzyło Stalinowi i Hitlerowi? Ponieważ uwierzyli w fałszywą wiarygodność, w miraż lepszego świata i w to, że nie tylko indywidualne „ja” się zgodziło na totalność nazistowską, faszystowską czy komunistyczną, ale reszta społeczeństwa również. Nie tylko ja, ale i inni członkowie proletariatu łączą się w jedną całość. Nie tylko ja, lecz i masa innych ludzi szczyci się swoimi aryjskimi korzeniami i gardzi odmiennymi rasami. Zbiorowe myślenie, zbiorowa odpowiedzialność i strach przed wykluczeniem, byciem innym, potencjalnym wrogiem narodu to zaprzeczenie politycznej egzystencji. Początkowo toleruje się mniejsze zło, zapominając następnie, że zło jest zawsze złem, aż w końcu zupełnie obojętniejąc na wszelkie anomalie i gwałty moralne - niszczy się polityczną egzystencję.

Dlaczego niektórzy sprzeciwili się i nie wspierali „polityki” ruchów totalitarnych? Ponieważ odważyli się samodzielnie myśleć i osądzać rzeczywistość. Sprzeciwiali się nie przez bunt, bo ten wydawał się wówczas niemożliwy, nie przez posiadanie lepszego systemu wartości, ale przez obojętność i pobudki czysto egoistyczne, ponieważ odpowiedzieli oni sobie na pytanie, do jakiego stopnia będę mógł żyć w przyjaźni ze sobą po popełnieniu pewnych czynów; i uznali, że lepiej doznawać krzywd, niż je czynić, lepiej nie robić nic, niż później nie móc żyć ze sobą w zgodzie ${ }^{31}$.

Dopiero w krytycznych sytuacjach nasza zdolność myślenia i osądzania wystawiana jest na próbę. W czasach pokoju i stabilności moralność rozumie się sama przez się. Ważne jest to, zdaniem Arendt, aby zawsze samodzielnie analizować i podejmować decyzje. Nie ma autorytetów, totalitarne ruchy odrzuciły tradycyjne definiowanie tego, czym jest autorytet. Kiedyś autorytet będąc fundamentalnym pojęciem polityki, stał się w czasach totalitaryzmów pojęciem kontrowersyjnym i niejasnym. Zapomniano bowiem, że tam, gdzie używa się przemocy, przymusu, a nawet autorytarnej perswazji, tam nie ma autorytetu. Autorytet opiera się na relacji pomiędzy dwiema osobami, z których jedna rozkazuje, a druga słucha, rozkazy jednak nie są nakazami, które bezzwłocznie należy wykonać; autorytet oparty jest na samej hierarchii, w której obie osoby mają swoje stałe miejsce, a przy tym zgodnie i dobrowolnie uznają jej słuszność i prawowitość ${ }^{32}$.

\footnotetext{
30 Tamże, s. 615-616.

31 Zob. H. Arendt, Odpowiedzialność zbiorowa, w: Odpowiedzialność i wladza sadzenia, wyd. cyt., s. $75-79$.

32 Zob. H. Arendt, Między czasem minionym a przyszlym, przeł. Mieczysław Godyń, Wojciech Madej, Warszawa 2011, s. 111.
} 
Straty, jakie ludzkość poniosła w efekcie totalitaryzmów, to nie tylko okrucieństwa, które nigdy nie powinny się wydarzyć i ogromne ilości zabitych ludzi, zniszczonych miast, kościołów, muzeów. To także zniekształcenie sensu polityki i rozbicie jej, niegdyś ścisłego, związku z wolnością. Totalitaryzm, żądający bezwzględnego podporządkowania wszystkich sfer życia wymogom polityki, przy równoczesnym nieposzanowaniu godności człowieka (zabierając mu prywatność) i jego praw jako obywatela (odmawiając prawa wolności od polityki), wywołał powszechne zwątpienie w jakąkolwiek, nawet minimalną, łączność polityki z wolnością. Co więcej, zwyciężyło ogólne przekonanie, że wolność zaczyna się tam, gdzie kończy się polityka ${ }^{33}$.

Społeczeństwo masowe oraz ruchy totalitarne pozbawiły ludzi ich rzeczywistej istoty, możliwości prawdziwego życia czynnie przejawiającego się poprzez współdziałanie i współdecydowanie o świecie. Arendt jednak wierzy, że mimo wszystko, po wyeliminowaniu przesądów w stosunku do polityki, przekonań, że wszystko, co z nią jest związane, oparte jest na kłamstwach i oszustwach fabrykowanych przez interesy i ideologie ludzi będących u władzy, człowiek na nowo zdecyduje się na realizowanie swego czasu wyznaczonego od narodzin do śmierci poprzez wspólne $\mathrm{z}$ innymi działanie w formie politycznej egzystencji.

\section{Summary}

The paper offers a view on Hannah Arendt's understanding of the political, and hence of the factors (structural rather than historical) that destroy true politics and human dignity. Her interpretation of a mass society is discussed as the result of confusing private and public spheres. In its fully-fledged form this results in totalitarian movements, which homogenise individuals thereby corrupting the political dimension of the common world. The author attempts to explain this process.

\section{Bibliografia}

Arendt, Hannah, Odpowiedzialność i władza sądzenia, przeł. Wojeciech Madej, Mieczysław Godyń, Warszawa 2006.

Arendt, Hannah, O rewolucji, przeł. Mieczysław Godyń, Warszawa 2003.

33 Zob. tamże, s. 182. 
Arendt, Hannah, Polityka jako obietnica, przeł. Wojciech Madej, Mieczysław Godyń, Warszawa 2008.

Arendt, Hannah, Kondycja ludzka, przeł. Anna Łagodzka, Warszawa 2000.

Arendt, Hannah, Korzenie totalitaryzmu, przeł. Daniel Grinberg, Mariola Szawiel, Warszawa 2008.

Arendt, Hannah, Między czasem minionym a przyszłym, przeł. Mieczysław Godyń, Wojciech Madej, Warszawa 2011.

Kymlicka, Will, Wspótczesna filozofia polityczna, przeł. Andrzej Pawelec, Warszawa 2009.

Le Bon, Gustaw, Psychologia ttumów, przeł. Bolesław Kaprocki, Kęty 2007.

Simmel, Georg, Wolność i jednostka, w: Sławomir Magala, Simmel, Warszawa 1980.

Smith, Adam, Teoria uczuć moralnych, przeł. Danuta Petsch, Warszawa 1989.

Skarżyński, Ryszard, Hannah Arendt. Budowanie myśli, „Literatura na świecie”, nr 6 (167), Warszawa 1985.

Swift, Adam, Wprowadzenie do filozofii politycznej, przeł. Anna Krzynówek, Kraków 2010. 